\title{
AEROSZOLOS PALACKOK GYÁRTÁSTECHNOLÓGIAI FEJLESZTÉSE A MISKOLCI EGYETEM ANYAGSZERKEZETI ÉS ANYAGTECHNOLÓGIAI INTÉZETÉBEN
}

\author{
Lukács Zsolt \\ projektvezetö, egyetemi docens, Miskolci Egyetem, Anyagszerkezettani és Anyagtechnológiai Intézet \\ 3515 Miskolc, Miskolc-Egyetemváros, e-mail: zsolt.lukacs@uni-miskolc.hu
}

\begin{abstract}
Absztrakt
A cikk a Mátrametál Fém Csomagolóeszköz Gyártó és Értékesitö Kft. és a Miskolci Egyetem konzorciumi együttmüködésében megvalósult Aluminium csomagolóeszközök (aeroszolos palackok) gyártásának fejlesztése c. projekt (GINOP-2-2-1-15-2017-00035) eredményeit foglalja össze. A projekt megvalósitása több munkacsoport összehangolt munkájával valósult meg. A cikkben az egyes témacsoportok tevékenységét és a megvalósitás során elért szakmai eredményeket mutatjuk be.
\end{abstract}

Kulcsszavak: aeroszolos palack, nyakbehúzás, nyakbehúzás alakitási határállapota

\section{Abstract}

In this paper, the development of aluminum packaging (aerosol cans) production will be summarised achieved within the project (GINOP-2-2-1-15-2017-00035). The project was implemented through the coordinated work of several workgroups. In this paper, the activities of each workgroup and their achievements are introduced.

Keywords: aerosol can, necking, formability limit of necking, numerical modelling of necking process

\section{Bevezetés, projekt előzmények}

Magyarország Kormánya a Széchenyi 2020 Európai Uniós pályázati ciklusban Gazdaságfejlesztési és Innovációs Operatív Program (GINOP) néven a vállalati kutatás-fejlesztési és innovációs aktivitás növelésére pályázati felhívást tett közzé 2015-ben. A felhívás célja „a hazai vállalkozások kutatásfejlesztési és innovációs tevékenységének növelése olyan kutatás-fejlesztési innovációs tevékenységek támogatásával, amelyek jelentős hozzáadott szellemi értéket tartalmazó, új, piacképes termékek, szolgáltatások, technológiák, továbbá ezek prototípusainak kifejlesztését eredményezik" [1].

A Mátrametál Kft. (mint, konzorciumvezető) a Miskolci Egyetemmel (mint, konzorciumi partnerrel) közösen adott be pályázatot az aeroszolos palackok gyártástechnológiájának fejlesztése céljából, amely eredményeként azt tüzte ki célul, hogy a piaci környezetben egyre inkább előtérbe kerülő un. új formavilágú aeroszolos palackok gyártása is lehetővé váljon a cég siroki üzemében. A kétkörös pályázati folyamat végén, a sikeres pályázati tevékenység eredményeként 2017. október elsejével elindult, 18 hónapos futamidővel az Alumínium csomagolóeszközök (aeroszolos palackok) gyártástechnológiájának fejlesztése c. projekt.

A sikeres pályázati anyag összeállításában, és a projekt szakmai előkészítésében elévülhetetlen érdemei vannak Prof. Dr. Tisza Miklós, professzor emeritusnak, aki több évtizedes pályázatírási és a képlékenyalakítás területén felhalmozott tapasztalatával segítette, hogy a pályázati anyag mind szak- 
mailag, mind formailag a lehető legnagyobb gondossággal készüljön el. Ezért mind a Mátrametál Kft. mind a Miskolci Egyetem ez úton is szeretné kifejezni nagyrabecsülését.

\section{A projekt célkitüzése, szakmai felépítése}

Az utóbbi néhány évben a kozmetikai ipar, mint az aeroszolos csomagolóeszközök legnagyobb felhasználója egyre több formai elemet felvonultató aeroszolos palackok előállítását követeli meg. Az aeroszolos palackokon megjelenő dizájnelemek előállítása a hagyományos palack előállítási technológiák fejlesztésének igényét teremti meg.

Az aeroszolos palackok formai kialakítása a palack, tárcsaszerủ előgyártmányának, hátrafolyatással történő alakításával kezdődik. Ennek eredményeként létrejövő hengeres, vékonyfalú $(0,25-0,35 \mathrm{~mm})$ pohárszerú alkatrész képezi az alapját az egyes formaelemek kialakításának. A formai elemek általában meghatározott rádiusszal kialakított átmérőcsökkentések, majd átmérő növelések sorozatából alakítják ki. A Mátrametál Kft. egyik jellegzetes, un. alakos kialakítású termékét mutatja be az 1. ábra.

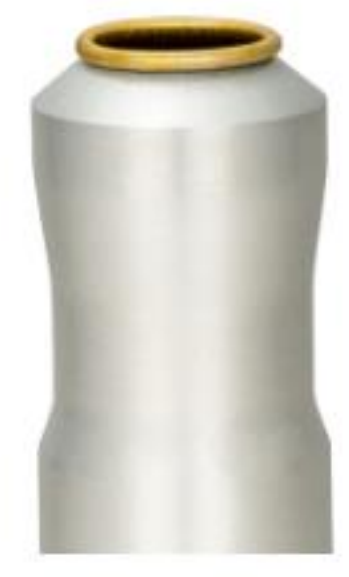

1. ábra. Alakos kialakitású aeroszolos palack.

Az ilyen jellegü palackok gyártási nehézsége abban áll, hogy az átmérő csökkentéseket, un. nyakbehúzó haragok sorozatával állítják elő oly módon, hogy az egyes alakítási lépések során létrejövő alakító erők a vékonyfalú palackok palástját terhelik, a palack aljának korlátozott hosszon történő megfogása mellett. Ezáltal az esetleg nem kellő körültekintéssel megválasztott, egy lépésben megvalósított átmérőváltozás miatt olyan erők is felléphetnek, amelyek a vékonyfalú palást stabilitásvesztését, összerogyását eredményezhetik. Ezért a technológusok a már sok évtizedes tapasztalattal felhalmozott átmérőváltozásokat, mint belső ipari szabványokat használják és ettől nem is szívesen térnek el.

A probléma abból áll, hogy a mai csomagolóeszközök formai világa jelentősen megváltozott. A paláston egyre nagyobb átmérőváltozásokat kell létrehozni és ezen átmérőváltozásokat a palack, szájától számítva, egyre mélyebben kell kialakítani. Ez által az alaki rész kialakítása egyre több húzási lépéssel és egyre kisebb megfogási hosszal jár.

Az egyenes palástú előgyártmány alaki részének és a palack szája alatti vállrésznek a kialakítását meghatározott fészekszámmal rendelkező, un. nyakbehúzó gépen állítják elő. A Mátrametál Kft-nél a projekt indulásakor a legnagyobb fészekszámmal rendelkező nyakbehúzó gép a Hinterkopf N30 típusszámú 30 fészekkel rendelkező berendezés volt. A berendezésen a 30 fészek közül csak korlátozottan 
lehet átméröcsökkentésre, növelésre felhasználni fészkeket, mert a fészkek jelenős részét más alakítási mủveletekre kell fenntartani. Ilyen mủveletek az egyenes palástú előgyártmány fenekének visszanyomása, a száj göngyölítése és a göngyölítés elötti esetleges falvastagságból történő forgácsolási müveletek, majd bizonyos termékeknél előírt peremesztergálási művelet. Ebből adódóan az alaki rész kialakítására, 3-5 a vállkialakításra 6-9 müveleti lépés marad.

Az új formavilágú aeroszolos palackoknál a Mátrametál Kft.-nél rendszeresített szerszámtervezési elvek alapján kialakított átméröcsökkentési és növelési stratégia nem minden esetben tette lehetővé, hogy beleférjenek az erre a müveletekre fenntartott fészekszámba. Ebböl a problémából kiindulva a projekt technológia fejlesztési céljai egyértelmúen megfogalmazhatók.

A projekt alapvető célkitüzése az volt, hogy egy közös $\mathrm{K}+\mathrm{F}+\mathrm{I}$ tevékenység eredményeként vizsgáljuk felül a jelenlegi szerszámtervezési elveket és ahol lehet, tegyünk ajánlásokat a szerszámtervezési gyakorlat átdolgozására. Ennek eredményeként álljon elő egy olyan belső szabványrendszer, amely világosan megfogalmazza a technológus mérnökök számára, hogy milyen lépések sorozatával és hogyan kell meghatározni az egyes technológiát megvalósító szerszámkészleteket.

Ha ezen áttekintő elemzés eredményeként megfogalmazható, hogy a piaci versenyképességet úgy lehet növelni, hogy az új formavilágú termékek elóállítására egy nagyobb fészekszámmal, és modernebb megfogó rendszerrel felszerelt nyakbehúzó gép beszerzése ajánlott, akkor ezen $\mathrm{K}+\mathrm{F}$ tevékenység támassza alá e beszerzés szükségességét.

Végül és nem utolsó sorban a beszerzés és a tervezési elvek átdolgozásával jöjjön létre olyan új formavilágú aeroszolos palack (prototípus), amely bővíteni tudja a Mátrametál Kft. termékpalettáját, ezáltal növelve a nemzetközi versenyképességét.

A fenti célkitüzések megvalósítására jött létre a 2 . ábrán bemutatott egymásba épüléssel 5 témacsoport, amely témacsoportok eredményeinek összességével a célkitüzések teljesíthetök. A következö alfejezetekben áttekintjük az egyes témacsoportok tevékenységét.

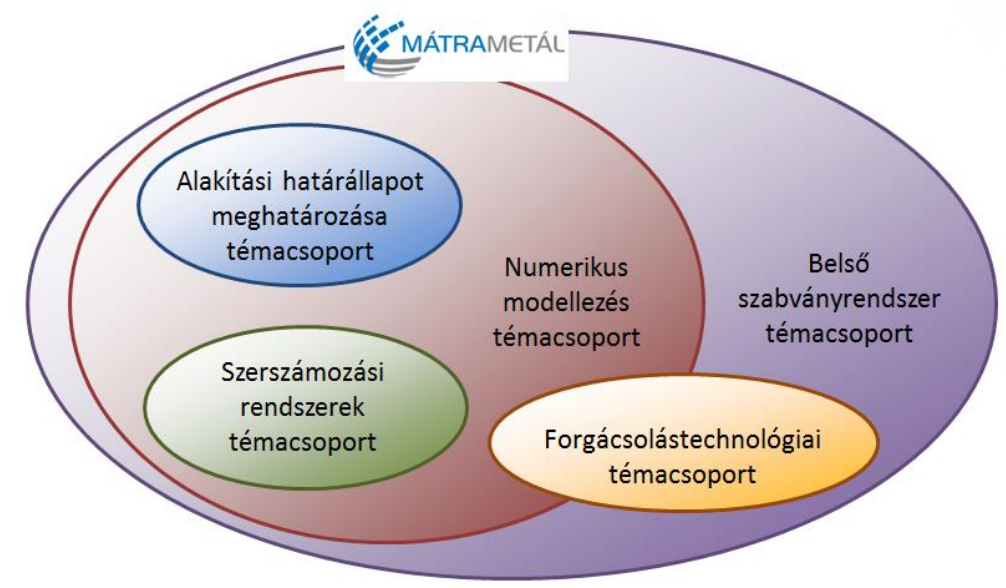

2. ábra. Az egyes témacsoportok egymásra épülése.

\subsection{Szerszámozási rendszerek témacsoport}

A szerszámozási rendszerek témacsoport, több altémacsoport munkáját fogja össze. Vezetője Dr. Gál Gaszton, címzetes egyetemi docens, aki szerszámkonstrukciós kérdésekben az Intézetünk legnagyobb tapasztalattal rendelkező, kollégája. Alapvető feladata a jelenlegi szerszámozási elvek megismerése. 
Ebbe a témacsoportba integrálódik a szerszám előállítás résztevékenységeit feltérképező szerszámanyag megválasztási, hőkezelési és az alakítási erőket relevánsan befolyásoló, a szerszámok felületei minőségét, súrlódási rendszerét kutató tribológiai altémacsoport.

A jelenlegi szerszámozási elvek megismerése alapvető jelentőséggel bír az átmérőcsökkentési és növelési stratégia tervezésére. Alapvető célkitüzése, hogy olyan világos szerszámtervezési elveket fektessen le, amelyek a lehető legnagyobb átmérő változást teszik lehetővé a technológia szempontjából még megfelelő biztonságú tartományon belül. Ez, az alakítási lépések számának csökkentését eredményezheti, ezáltal összetettebb formavilággal rendelkező aeroszolos palackok gyárthatók.

\subsection{Alakítási határállapot meghatározása témacsoport}

Az egyes átmérő változásokat az határolja be, hogy az előgyártmány alakítási erő által okozott igénybevétel az adott geometriára vonatkozó teherbíró képesség határállapotát ne lépje túl. Ennek megismerése azért fontos, mert az egymást követő alakok különböző teherbíró képességgel rendelkezhetnek, amit a jelenlegi szerszámtervezési gyakorlat nem használ ki. Általános elvként az fogalmazható meg, hogy a megkívánt átmérőváltozásokat egyenközüen felosztott átmérő változtatási lépések sorozatával állítják elö.

A határállapotok megismerésével lehetőség adódhat az átmérő változtatási stratégia átdolgozására, így értékes müveleti lépések szabadulhatnak fel, növelve a formavilág sokszínüségét is. Az alakítási határállapot meghatározása nem nélkülözheti a fizikai méréseket sem, amelyek megvalósítása a tömegtermelés akadályoztatása nélkül csak különálló mérőkészüléken végzett fizikai mérésekkel valósítható meg. Ennek megtervezése és kialakítása a mérések elvégzése és kiértékelése szintén ennek a témacsoportnak a feladata. A témacsoport vezetését Dr. Kovács Péter Zoltán, egyetemi docens végezte, aki az alakítási határállapotok meghatározása területén mind a hazai, mind a nemzetközi viszonylatban elismert kutatási tapasztalattal rendelkezik.

\subsection{Numerikus modellezés témacsoport}

A mai modern számítógépi, un. numerikus modellezési lehetőségek olyan eszközrendszer alkalmazását teszik lehetővé a mérnöki gyakorlat szinte minden területén, amelyekkel a sokszor idő- és költségigényes fizikai kísérletek száma jelentősen csökkenthető. Nincs ez másként az alakítási folyamatok modellezése területén sem. A Miskolci Egyetem több évtizede kutatja és használja a különféle numerikus modellezési alkalmazásokat így a mérnöki tevékenységek numerikus modellezésének szinte minden területére van releváns tapasztalatokkal rendelkező kolléga.

A nyakbehúzási műveletek modellezést Dr. Krállics György egyetemi tanár vezetésével müködő kutatócsoport végezte. Krállics professzor úr több évtizede folytat nemzetközileg is elismert kutatásokat a különféle képlékenyalakítási műveletek numerikus modellezése területén. A témacsoport egyik fö feladata, hogy a korlátozott fizikai mérések tartományát virtuális térben kiterjesztve megsokszorozza az alakítási határállapot meghatározásának megítélését segítő kísérletek eredményeit. Egy ilyen vállkialakítási művelet numerikus modellezésének eredménye látható a 3 . ábra a) részletén.

A numerikus modellezés témacsoport másik fontos feladata az egyes alakítási műveletek eredményeként előállt félkész termékek teherbíró képességének meghatározása. Mivel a fizikai mérések száma ebben az esetben is korlátozott. Ehhez a modellezéshez másfajta megközelítés (modellalkotás) alkalmazása szükséges. Szerkezetek teherbíró képességének numerikus vizsgálatában a Miskolci Egyetem Mechanikai Intézetének vannak releváns tapasztalatai, ezért e modellezési tevékenységet a Dr. Baksa Attila által irányított kutatócsoport végezte. Feladatuk az egyes geometriai kialakítással 
rendelkező félkész termékek kihajlási (palást-rogyasztási) erejének meghatározása, ezáltal a fizikai mérések eredményeinek virtuális úton történő kiterjesztése az alakítási határállapot meghatározása céljából. Egy ilyen határállapothoz tartozó alak látható a 3. ábra b) részletén.

A Numerikus modellezési témacsoport felépítésének sokszínűsége jól mutatja az Intézetek, Karok közötti együttmüködést egy mérnöki feladat megoldása területén.

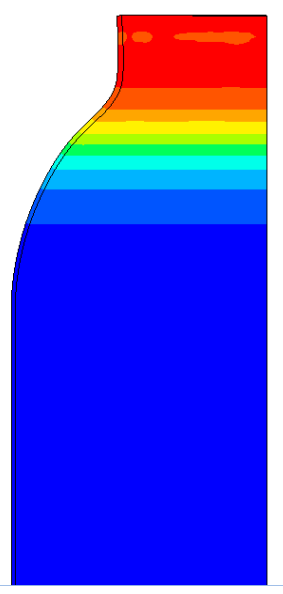

a)
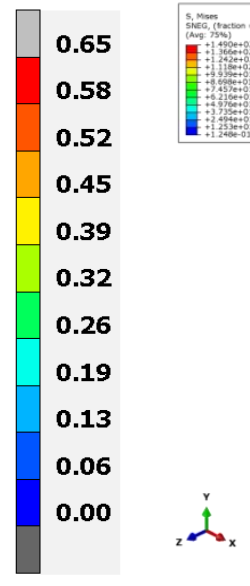

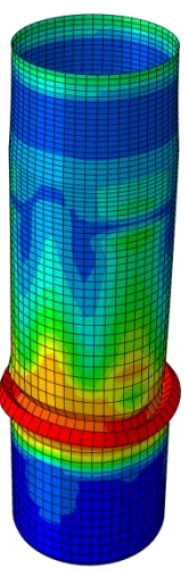

b)

3. ábra. a) Vállkialakítás numerikus vizsgálata. b) Vékonyfalú héjszerkezet tönkremenetelének numerikus modellezése.

\subsection{Forgácsolástechnológiai témacsoport}

A palack szájának kialakítása (göngyölítés) után egyes megrendelöi kéréseknek megfelelően un. peremesztergálási (homlokesztergálási) mủveletet kell végezni a nyakbehúzó berendezés egyik állomásán. A gyártói tapasztalatok szerint itt sok esetben keletkezik nehezen kezelhető folyó forgács, ami egyes esetekben nem megfelelő minőségü termékhez vezet. Dr. Maros Zsolt, a Gyártástudományi Intézet intézetvezetője által irányított forgácsolástechnológiai témacsoport elsődleges feladata e forgácsolási művelet fejlesztése, a folyamat mélyreható megismerése során.

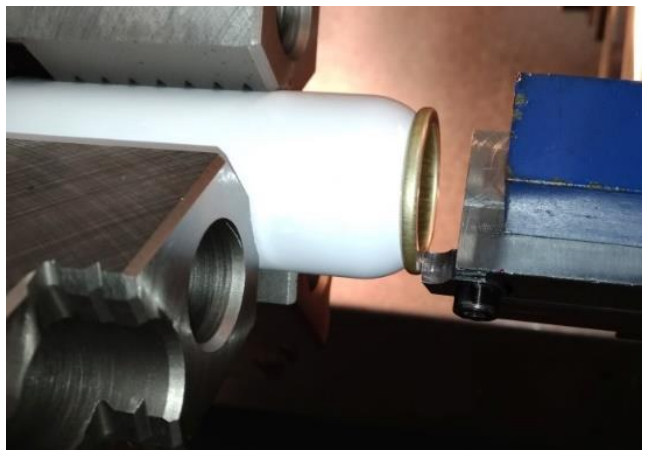

a)

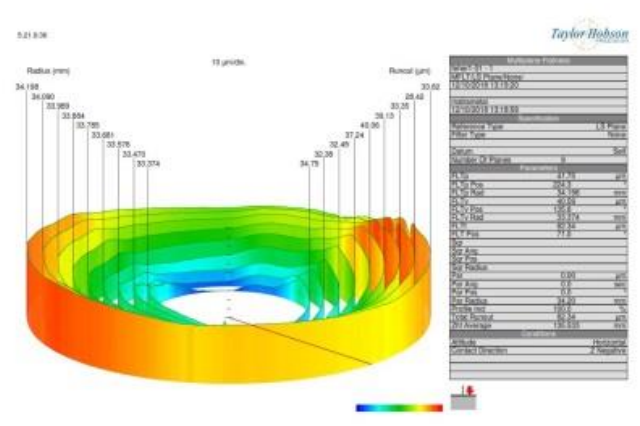

b)

4. ábra. a) Forgácsolási kisérlet. b) Felület topográfiai mérés eredménye. 
Ehhez a Gyártástudományi Intézet laboratóriumában a jelenlegi forgácsoló élgeometriával forgácsolási kísérleteket végeztek ahol lehetőségük volt a forgácsolás technológiai paramétereinek a forgácsképződésre gyakorolt hatását vizsgálni. A 4. ábra a) részletén egy ilyen forgácsolási kísérlet fényképe látható.A forgácsolási kísérletek eredményeként előállt és a Mátrametál Kft-től a jelenlegi termelésből beszállított aeroszolos palackok száján a Intézet felülettopográfiai laboratóriumában méréseket végeztek. Egy ilyen felülettopográfiai mérés eredményének grafikus megjelenítése látható a 4. ábra b) részletén.

\subsection{Belső szabványrendszer témacsoport}

A belső szabványrendszer témacsoport, mint ahogy azt a 2. ábra is szemlélteti, az egyes témacsoportok tevékenységeinek eredményeit foglalja össze kialakítva egy olyan új belső tervezési-, gyártási-, üzemeltetési előírásrendszert, ami a Mátrametál Kft. minőségbiztosítási rendszerét fejlesztheti. A belső szabványrendszerek témacsoport vezetője Szilágyiné Dr. Bíró Andrea, egyetemi docens.

\section{A projekt eredményei}

A projekt 18 hónapos futamideje alatt az egyes tématerületeken számtalan fizikai, numerikus és modellkísérlet zajlott, amelyek eredményeinek maradéktalan bemutatására e publikáció terjedelmi korlátai miatt nem vállalkozhatunk. Ennek figyelembevételével a projekt eredeti célkitüzéseit szem előtt tartva a következő alfejezetekben röviden összefoglaljuk a legkézzelfoghatóbb eredményeket.

\subsection{Nyakbehúzási lépés mérőkészülékének tervezése}

A nyakbehúzó készülék a Miskolci Egyetemen hasznosuló projekt eredmények közül talán az egyik legjelentősebb. Segítségével kellő számú fizikai kísérletet végezhettünk mind az alakítás erőszükségletének, mind az alakítási határállapothoz tartozó erő tekintetében.

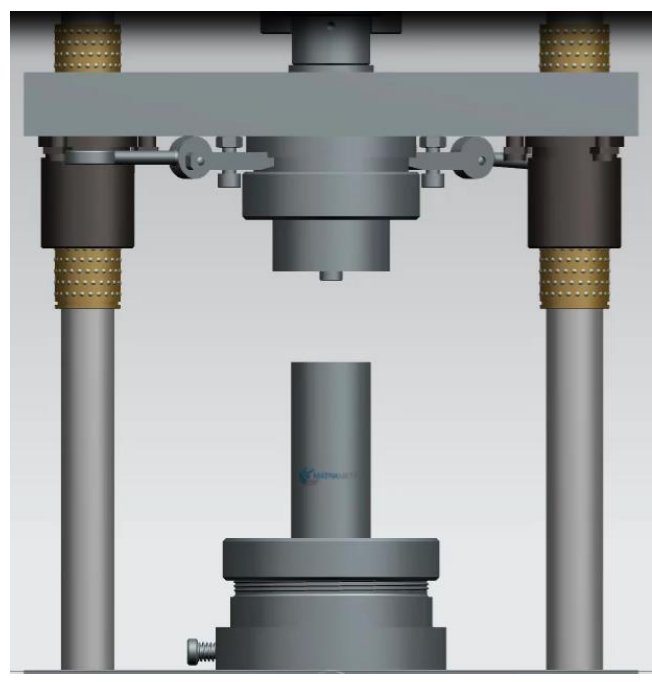

a)

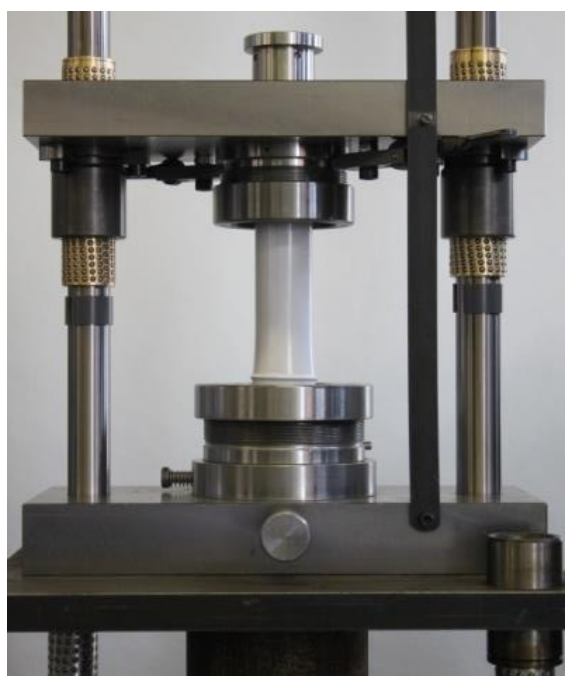

b)

5. ábra. a) A mérökészülék CAD modellje. b) A legyártott mérökészülék fotója. 
A mérések segítségével a numerikus témacsoport numerikus modellezési eredményeit sikerült azonos körülmények között a fizikai mérésekkel is igazolni, így a virtuális kísérletek validálását elvégezni.

A mérőkészülék szerszámcsatlakozási kialakításánál fogva alkalmas az üzemben használt szerszámkészletek fogadására, így a tömeggyártás előtti prototípus kísérletek elvégzésére is. Az 5. ábra a) részletén a mérökészülék $3 \mathrm{D}$-s $\mathrm{CAD}$ modellje látható, az ábra $\mathrm{b}$ ) részletén a fizikailag megvalósult mérőkészülék fényképe látható. A mérőkészülék alkatrészeinek jelentős részét a Mátrametál Kft. forgácsoló üzemében állították elő. Az 5. ábra b) részletén bemutatott mérőkészülékkel gyártottuk le az ME ATI Intézetének MTS típusú univerzális elektro-hidraulikus anyagvizsgáló berendezésén a későbbi fejezetben a 8 . ábra b) részletén bemutatott prototípus aeroszolos palackot. Ez a mérőkészülék lehetővé teszi az új formavilágú palackok gyártásának vizsgálatát a sorozatgyártás hátráltatása nélkül, ezáltal a szerszám fejlesztési ideje csökkenthető és a gyártással párhuzamosítható.

\subsection{Súrlódási tényező mérése}

A numerikus modellezés egyik legnagyobb kihívása a valósággal jó egyezést mutató eredmények elöállítása, ami alapvetően a modellalkotás során hozott egyszerüsítéstől függ. A numerikus modellezési vizsgálatok során azt tapasztaltuk, hogy az alaki rész és a vállkialakítás alakítási erőszükségletét a szerszám és a palack alakítás közbeni súrlódási folyamatai erőteljesen befolyásolták. Ez teljesen összhangban van a termelésben tapasztaltakkal. A tribológiai rendszert tovább bonyolították a különbözö külső lakkozással ellátott aeroszolos palackok. Ezért a numerikus modellezés támogatására szükség volt egy, a tényleges anyapárosításokkal és bevonatokkal végzett súrlódási tényező mérési készülékre. A készüléknek a következő követelményrendszert kellett kielégíteni:

- Egyszerre kellett alkalmasnak lenni az aeroszolos palackok külső és belső felületeinek vizsgálatára;

- a Mátrametál Kft-nél járatos méretủ palackok mindegyikén is képes legyen mérni;

- az eredmények egyszerüen kiértékelhetők és számszerüsíthetők legyenek.

A felállított követelményrendszert maradéktalanul kielégítő mérőkészülék képe látható a 6 . ábra a) részletén. A 6. ábra b) részlete a különböző tribológiai rendszerek mérési eredményeit tartalmazza oszlopdiagram formában.

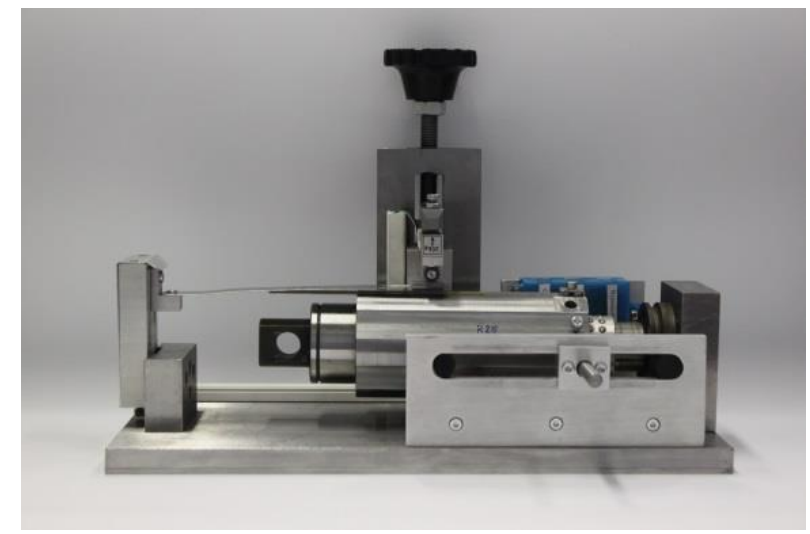

a)

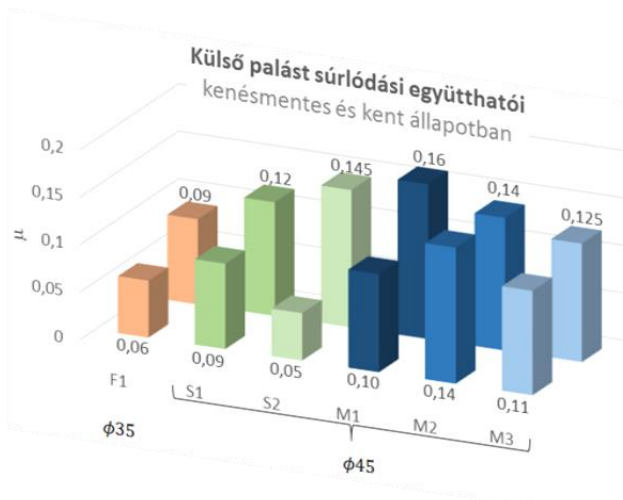

b)

6. ábra. a) Mérökészülék súrlódási tényezö meghatározására. b) Különbözö peremfeltételekkel meghatározott súrlódási tényezö értékei. 


\subsection{Tervezési nomogram előállítása}

A tervezési nomogram a fizikai mérések és azok vizsgálati tartományát numerikusan kiterjesztett mérési eredményeinek összességét jeleníti meg a technológiai- és szerszámtervező mérnökök számára, egyszerüen felhasználható grafikus formában. A tervezési diagram müködése a 7. ábrán követhető figyelemmel.

Alapvetően a minimális szükítési átmérőt a palack geometriai kialakítása meghatározza. Ezért az ehhez gyártandó szúkítő harang geometriai méretei adottak. Ha az alakítás során a palack palástja, az ismert szerszámmérethez tartozó ívhossz mentén érintkezik az itt fellépő erő terheli a vékonyfalú palástot kihajlás szempontjából adott palackbefogási hossz mellett. Nyilvánvaló, hogy nagyobb érintkezési ívhosszaknál nagyobb alakító erők és ezzel, nagyobb igénybevétel lép fel. A diagramon az egyes érintkezési ívhosszakhoz meghatároztuk a tönkremeneteli erő értékét. Ez látható folytonos fekete vonallal, ami a fellépő alakító erőket lehatárolja. Ha az érintkezési ívhosszból adódóan ettől nagyobb erő lép fel (a monogram piros színnel jelölt tartománya) a palackpalást összerogy.

A 7. ábra azt az esetet mutatja, amikor az adott átméröcsökkentést két lépésre osztjuk és ehhez, itt nem részletezett szerszámtervezési elvek felhasználásával egy előhúzó, majd egy készrehúzó haragot tervezünk. Az ábrán zöld folytonos vonallal az érintkezési ívhossz függvényében fellépő (alakító erőt) a palástot kihajlásra terhelő erőt olvashatjuk le. Mindaddig, amíg ez a szerszámgeometriák által meghatározott érintkezési ívhosszak tekintetében a nomogram zöld területére esik, addig az alakítás tönkremenetel nélkül elvégezhető. Az adott ívhosszak tekintetében az is látható, hogy a tönkremeneteli erőhöz képest az adott szükítő harang geometria a megengedhető tartomány hány százalékát használja ki.

A nomogram használatának előnyét megtapasztalhattuk az új formavilágú (prototípus) palackok szerszámainak tervezése során. A nomogram lehetőséget biztosít nagyobb tervezői gyakorlattal nem rendelkező mérnökök számára, hogy a szerszámtervezési folyamat során hozott döntéseiket leellenőrizhessék. A nomogramokat egységes rendszerbe foglalva a belső szabványrendszer tartalmazza.

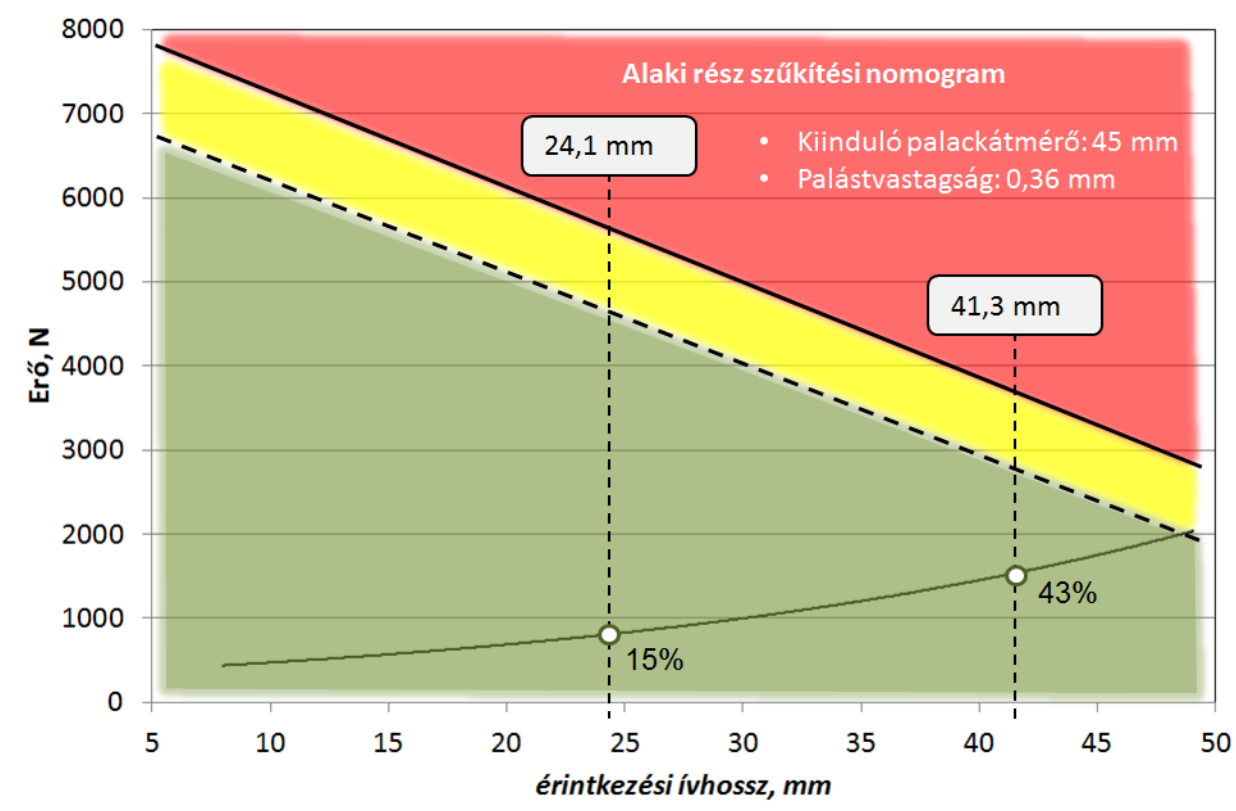

7. ábra. Átmérö csökkentési (szükitési) diagram $45 \mathrm{~mm}$ kiinduló palackátméröre. 


\section{4. Új nyakbehúzó gép beszerzése, prototípusgyártás}

A vizsgálataink során egyértelmüvé vált számunkra, hogy ha követni akarjuk a piac által diktált új formavilágú palackok geometriai kialakítását a palack szájától mért alakítási maximális úthossz korlátoz bennünket a legjelentősebb mértékben. A Mátrametál Kft.-nél alkalmazott Hinterkopf N30-as nyakbehúzó berendezés megfogó rendszere nem alkalmas mélyebben kezdődő formaelemek kialakítására.

Ezért a projekt által biztosított támogatás segítségével 2018. decemberében közbeszerzési eljárás keretein belül beszerzésre került a Hinterkopf cég N40.2 típusjelzésủ nyakbehúzó berendezése, amely mind a fészekszámát tekintve (40 fészkes), mind a megfogási hossz csökkenése (50 mm-ről $30 \mathrm{~mm}$-re) miatt új formavilágú aeroszolos palackok gyártását teszi lehetővé.

A beszerzéssel párhuzamosan a Mátrametál Kft. szakemberei egy lehetséges új formavilágú aeroszolos palack tervezését kezdték meg a projekt eredményeinek felhasználásával. A legyártásra került szerszámelemekkel prototípusgyártást végeztek a Miskolci Egyetem közremüködésével az új szerszámkészletek vizsgálatát lehetővé tévő mérőkészüléken laboratóriumi körülmények között, aminek kedvező tapasztalatai után az új nagybehúzó gépen, termelésben is kipróbálhatták az új formavilágú aeroszolos palack gyártását.

A 8. ábra a) részlete az új beszerzésủ nyakbehúzó berendezést, b) részlete az új formavilágú aeroszolos palackot mutatja.

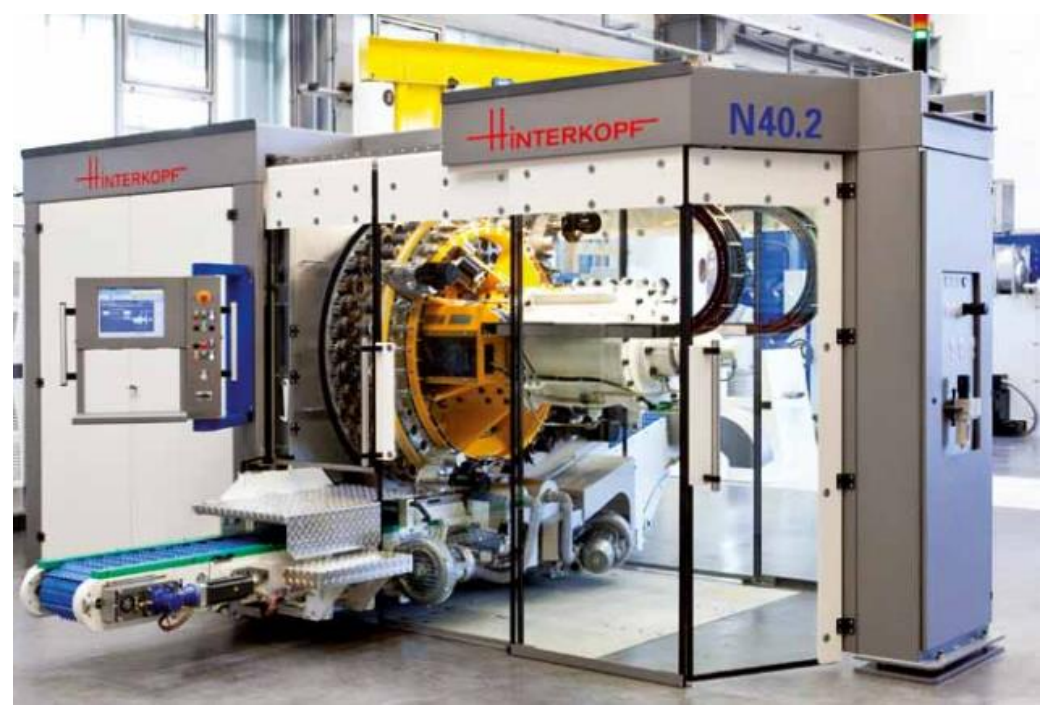

a)

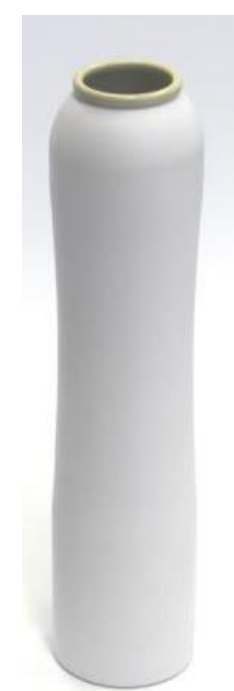

b)

8. ábra. a) A Hinterkopf N40.2 nyakbehúzó berendezés. b) Új formavilágú aeroszolos palack.

\section{4. Összefoglalás}

Cikkünkben bemutattuk, a Mátrametál Kft. és a Miskolci Egyetem közös konzorciumi együttmüködésében megvalósult „Alumínium csomagolóeszközök (aeroszolos palackok) gyártásának fejlesztése c. projekt logikai felépítését és eredményeit. A kézzelfogható eredmények között meg kell említenünk a projekt támogatásával megtervezett és legyártott nyakbehúzási müvelet fizikai modellezést lehetővé 
tévő mérőkészüléket, amely az új formavilágú aeroszolos palackok tömeggyártása előtt lehetőséget biztosít az egyes szerszámkoncepciók vizsgálatára.

A nyakbehúzási folyamat numerikus modellezésével elóállított technológiai tervezést támogató nomogram lehetőséget biztosít a technológus mérnökök számára az új formavilágú aeroszolos palackok nyakbehúzásánál alkalmazott szerszámkészletek geometriai kialakításának megtervezésére.

A projekt Mátrametál Kft.-nél megvalósuló kézzelfogható eredményének a technológiai- és szerszámtervezési gyakorlat áttekintéséből és annak tapasztalataiból megvalósuló új nyakbehúzó berendezés beszerzését tekintjük.

Mind a tervezési nomogram, mind az új nyakbehúzó berendezés segítségével sikeres prototípus elöállítás valósult meg, amely így tovább szélesíti a Mátrametál Kft. termékpalettáját, növelve piaci versenyképességét.

\section{Köszönetnyilvánítás}

A cikkben ismertetett kutató munka a GINOP-2.2.1-15-2017-00035 jelü „Alumínium csomagolóeszközök (aeroszolos palackok) gyártásának fejlesztése" projekt részeként - a Széchenyi 2020 keretében - az Európai Unió támogatásával, az Európai Szociális Alap társfinanszírozásával valósul meg.

Az egyes témacsoportok bemutatásánál szerzőként arra törekedtem, hogy jelenjenek meg azok a kollégák, akik a Miskolci Egyetem más Karairól vagy mási Intézeteiből kerültek bevonásra a projekt megvalósítása során.

A projekt szakmai koordinálását Miskolci Egyetem részéről a Gépészmérnöki és Informatikai Kar, Anyagszerkezettani és Anyagtechnológiai Intézete végezte és oroszlánrészt vállalt a szakmai megvalósításban is. Ezért itt szeretném köszönetemet kifejezni az ATI Intézet teljes kollektívájának, akik ki-ki a maga területén végzett munkájával segítette a projekt sikeres megvalósítását.

Szeretném továbbá köszönetemet kifejezni Prof. Dr. Lukács János intézetigazgató úrnak, hogy lehetöséget biztosított az Intézet (mind dologi és mind humán) erőforrásainak hasznosításához.

A Miskolci Egyetem, mint konzorciumi partner projektvezetőjeként szeretném megköszönni azt a példaértékü együttmüködést, amit ebben a projektben a Mátrametál Kft. menedzsmentje és müszaki területen dolgozó kollégái oldaláról tapasztaltam.

És végül, de nem utolsó sorban külön köszönet illeti meg Prof. Dr. Tisza Miklós professzor emeritust a projekt előkészítésében végzett munkája elismeréseként.

\section{Irodalom}

[1] Nemzeti Kutatási Fejlesztési és Innovációs Hivatal: Vállalatok $\mathrm{K}+\mathrm{F}+\mathrm{I}$ tevékenységének támogatása GINOP 2.2.1-15 Felhívás, (palyazat.gov.hu) 2015. 